\title{
Management
}

UDC 303.4:001

doi: 10.12958/1817-3772-2020-4(62)-110-118

H. Dzwigol,

ORCID 0000-0002-2005-0078,

e-mail: henryk.dzwigol@poczta.fm,

Silesian University of Technology, Gliwice (Poland),

London Academy of Science and Business, London (United Kingdom), Sumy State University, Sumy (Ukraine),

\section{TOOLS FOR ADJUSTING RESEARCH METHODS AND TECHNIQUES TO RESEARCH PROCESSES}

\section{Introduction}

Strategic management is a process that has been primarily focused on changes taking place in corporate environment. Its core refers not only to activities necessary for achieving strategic goals, but it also means a manner of considering management in terms of its individual functions (Barney, and Hesterly, 2010). The aim of strategic management is to create long-lasting conditions for the functioning of enterprises and to achieve a favourable market position by maintaining or increasing certain success factors (success potential) (Ansoff, et al., 2018). The special features of strategic management in a company are: focus on the company's environment; systematic observation of macroeconomic changes in the company's environment; analysis of regional and global relations; and analysis of behaviours of competitors, suppliers and customers (Best, et al., 2007). Strategic management is a constant quest for both conditions of success and sources of failure. (Hitt, and Duane Ireland, 2017). Thus, the basis for strategic company management involves information, as comprehensive as possible, on economic development trends and on strengths and weaknesses of the company itself and its competitors (Trigeorgis, and Reuer, 2017). Modern organisations relying on the development of information technology are forced to more effectively combine strategic objectives with current management practice.

In modern management, the quality of the thinking process becomes a subject of research and analysis. It influences the accuracy and quality of decisions being made.

Modern management sciences have rejected methodological fundamentalism - stringently defining the scientific character of a method and evoking neo-positivist models in natural sciences (Danermark, 2005). In the literature related to management sciences (Ogiela, 2017; Raziq and Wiesner, 2016) the necessity of applying various methods of exploring and shaping an organisation has been stressed many a time. The literature also points out that there is a need to simultaneously apply multiple mutually verifying and correcting methods (Ares and Varela, 2018).

Methodics can be defined as a set of ways, rules and principles regarding how a given job needs to be done. Nonetheless, one needs to ponder the specific character of methodics related to management sciences. In the subject-related literature there is a belief that management sciences are underdeveloped as far as methodology is concerned. The said underdevelopment is caused, among others, by the anti-methodological character of the main trend (Punch, 2016; Quian, 2018).

In the literature, one may additionally identify some statements that have confirmed the poor methodology-related character of management sciences as well as have emphasised the necessity to effectively achieve knowledge (Gordon, et al., 2018), methods and techniques borrowed from other sciences' research tools (Dźwigoł, 2019; 2020a; 2020b; 2020c; Dźwigoł, et al., 2019; 2020a; 2020b; Dźwigoł and Dźwigoł-Barosz, 2019; Kwilinski et al., 2020a; 2020b). It is always underlined that identifying and developing methods specific only for management sciences are not needed (Bryman, 2006); on the other hand it is necessary to integrate, in transdisciplinary fashion, overly specialised sciences (Vaivio and Sirén, 2010).

Nonetheless, the inferencing about the poor methodological state of management sciences turns out to be far-fetched. It needs to be emphasised that one is able to identify, among various methods employed in the management sciences, both the methods emblematic for management as well as the methods borrowed from other scientific disciplines. The borrowed methods involve, in most cases, familiarising oneself with the an organisation and its management, whereas the researchers' own methods are aimed at developing the organisation itself and a system of its management.

Moreover, there has appeared methodological pluralism. It states that in order to solve a research problem, one needs to be ready to apply other research methods derived from various theoretical disciplines and approaches. It means that 'diverse points of view are combined with diversity and a variety of research ways, methods and techniques, as well as attempts to transform the world' (Krzyżanowski, 1999). However, these proceedings result very often in anarchism as well as methodological eclecticism. With reference to the foregoing, in order to achieve reliable research findings, it is necessary to meticulously analyse the problem being researched and to select such research methods that would allow the curbing of the above-mentioned phenomena. 
The aim of this paper is to present a tool for selecting research methods and techniques for the research process, developed by the author himself (Dźwigot, 2018).

\section{Research method}

In the beginning, the model and procedure were developed on the basis of method-related assumptions characterising models, processes or methods of carrying out research processes within the scope of management sciences. Findings acquired from the carried-out analysis of domestic and foreign literature (Robbins, 2009; Thomas, 2017; Boiko et al. 2019; Czyżewski et al., 2019; Cyfert et al., 2020; Czakon et al., 2020; Chygryn et al., 2020; Dalevska et al., 2019; Dementyev \& Kwilinski, 2020; Drozdz et al., 2019; 2020; Dubina et al., 2020; Dyduch, 2019a; 2019b; Dźwigoł, 2018; 2019a; 2019b; 2020a; 2020b; 2020c; Dzwigol \& Wolniak, 2018; Dzwigol, \& Dźwigoł-Barosz, 2018; Dzwigol \& Dzwigol-Barosz, 2020; Dzwigol et al., 2019a; 2019b; 2019c; 2020d; 2020e; Furmaniak et al., 2018; 2019a; 2019b; Gorynia, 2019; Gorynia, et al., 2019; Kamińska, 2018; Kharazishvili et al., 2019; 2020; Klimas et al., 2020; Kondratenko et al., 2020; Kuzior et al., 2019; Kwilinski, 2017; 2018a; 2018b; 2018c; 2018d; 2019; Kwilinski et al., 2019a; 2019b; 2019c; 2019d; 2019e; 2019f; 2019g; 2020a; 2020b; 2020c; Kwilinski \& Kuzior, 2020; Lakhno et al., 2018; Lyashenko \& Pidorycheva, 2019; Miskiewicz, 2017a; 2017b; 2018; 2019a; 2019b; 2020; Miśkiewicz \& Wolniak, 2020; Pająk et al., 2016; 2017; Saługa et al., 2020; Savchenko et al., 2019; Tkachenko et al., 2019a; 2019b; 2019c; 2019d; 2019e; Trapczyński et al., 2019; Trushkina et al., 2020; Vyshnevskyi, 2019; Yelnikova \& Miskiewicz, 2020; Zaloznova \& Trushkina, 2019; Zastempowski et al., 2020) have unequivocally confirmed that it is difficult, already at the phase of defining research problems, to select one method allowing the diagnosis of a problem comprehensively and thoroughly. It is thus necessary to employ various research methods that would give a complex answer to the posed problem. The very development of heterogenous cognitive methods, modelling or organisation management has an impact on the necessity to adopt an open-minded approach, allowing or even encouraging the combining of numerous approaches and methods (Punch, 2016; Quian, 2018; Quinton and Reynolds, 2018). In order to develop a universal procedure, experts defined, within the course of consultations, five elements to be taken into consideration upon selecting methods and techniques suitable for the research process, including theses, hypotheses and research questions:

- selecting a research subject - defining what object lies in the interest of a given researcher;

- determining the character of the carried-out research - the researcher should precisely define a type, character and kind of the carried-out research;

- determining the research transparency - literature-based inference and practical experience show that the aim of the research may be presented in various ways depending on its defined character. In the given case, the researcher should state what method he/she is going to use to present a predefined aim of the carried-out research;

- selecting a way in which the research study is carried out - conclusions reached on the basis of methods and techniques described in the source literature prove a multi-dimensional commitment of the researcher in the ongoing considerations. What is more, it needs to be determined, in the first place, what rudimentary types of researchers' involvement in the process of carrying out the research process are. Then, one should select the methods and techniques that fulfil the presented conditions;

- determining the size of the sample being researched - it is the last criterion, specified by experts, which makes the availability of the given sample more precise. Assigned methods and techniques of conducting research processes are often dependent on the sample size (some of them are destined to assess smaller populations, whereas other are to evaluate larger ones).

Further on, the author presented his own (Dźwigol, 2018) division of components (modules) of the advocated research process, as defined by experts (see the Table below).

\section{Division of module components in the procedure for adjusting (selecting) methods}

Table and techniques to the carried-out research process

\begin{tabular}{|c|c|c|c|c|}
\hline Research subject & $\begin{array}{l}\text { Character of the } \\
\text { research studies }\end{array}$ & $\begin{array}{c}\text { Transparency } \\
\text { of the research goal }\end{array}$ & $\begin{array}{l}\text { Ways of conducting } \\
\text { research studies }\end{array}$ & $\begin{array}{c}\text { Size of the } \\
\text { researched sample }\end{array}$ \\
\hline $\begin{array}{l}\text { Business entity, } \\
\text { personal aspect, } \\
\text { case (case study), } \\
\text { phenomenon, } \\
\text { environment, } \\
\text { process }\end{array}$ & $\begin{array}{l}\text { Identifying/ explora- } \\
\text { tive, } \\
\text { secondary, } \\
\text { experimental, } \\
\text { diagnostical, } \\
\text { model-related, } \\
\text { analytical }\end{array}$ & $\begin{array}{l}\text { Non-disguised, } \\
\text { disguised }\end{array}$ & $\begin{array}{l}\text { Indirectly, } \\
\text { directly, } \\
\text { participating, } \\
\text { non-participating }\end{array}$ & $\begin{array}{l}\text { Below } 20 \text { observa- } \\
\text { tions, } \\
\text { from } 20 \text { to } 50 \text { obser- } \\
\text { vations, } \\
\text { from } 50 \text { to } 100 \text { ob- } \\
\text { servations, } \\
\text { from } 100 \text { to } 250 \text { ob- } \\
\text { servations, } \\
\text { above } 250 \text { observa- } \\
\text { tions }\end{array}$ \\
\hline
\end{tabular}

Source: the author's own work. 
Then, by means of group assessment by experts, carried out by means of a form, one was able to classify selected methods and techniques within the framework of the adopted division of modules in the elaborated procedure. The classification process involved five experts, i.e.:

- two practitioners, carrying out research studies within the scope of their basic managerial activities;

- two representatives of management sciences;

- one statistician analysing data resulting from the carried-out research studies.

The survey form consisted of five parts corresponding to subsequent modules of research procedures (i.e. research subject, character of the carried-out research studies, transparency of the research goal, ways of conducting research studies and size of the research sample). Each of the five parts was designed in the form of a matrix, containing respectively: in the columns methods $^{1}(17)^{2}$ or techniques ${ }^{3}(29)^{4}$, in the rows - priorly identified constituents of the procedure of selecting methods and techniques for the research process in management sciences.

As a result of the conducted research study, one achieved an advocated division of research methods and techniques with regard to their subject, number, character, aim or a manner in which the study is to be carried out.

\section{Procedure of selecting methods and tech- niques for research processes within ma- nagement sciences}

Phase I-Selecting a research subject (Dźwigot, 2018) - it involves designating a real research subject, determining its quantity (cases), features, and components, as well as ways and possibilities to address it.

A starting point of the phase is a recommended classification of research methods and techniques in terms of the research subject compliant with components of the phase:

- Business entity - all organisational units carrying out business activities for profit-making purposes (within the scope of organisational structures). Within the said category, any business models, relations in organisational structures, etc. are taken into consideration.

- Personal aspect - staff (of various levels), behavioural patterns and organisational culture in the company. Within the scope of the category, staff's competences, their knowledge, progress in meeting organisational goals, etc. are put under scrutiny.

- Case study - a detailed case; a real event is subject to analysis.

- Phenomenon (economic, social, etc.) - any and all events related to the business activity, affecting the said entities.

- Environment - nearer and farther environment; within the scope of this category, broadly understood, interested parties are taken into consideration - e.g. competitors, clients, suppliers and the society treated as an aggregate.

- Process - each act/action undertaken to achieve a determined effect. Within the category, internal and external processes, initiated by economic entities, are subject to analyses.

The starting point of the phase is a set of methods and techniques, gathered with regard to the selected research subject, as the latter shall be a point of departure in the next phase of the procedure execution. The cascade-like (step-by-step) execution of the procedure allows one to eliminate methods and techniques that fail to meet the coherence requirements as with respect to all phases of the procedure.

Phase II - Determining character of the carriedout research (Dźwigot, 2018) - it specifies the reason why researchers undertake to deal with a given research problem as contained in the analysis, hypothesis or research question being analysed. In this phase, the researcher chooses the character of the research goal.

- Identifying - preliminary research studies; their aim is to identify a problem.

- Secondary - the research studies involve an analysis of existing and widely available data, gathered earlier.
${ }^{1}$ Methods: documentation analysis, survey, biographical survey, self-monitoring checklists, in-lab experiment, field (natural) experiment, expert group assessment, scenario-based method, observation, pseudo-experiment, psychography, other people's statements, projective tests, psychological tests, fitness tests, knowledge tests, interview.

${ }^{2}$ Only methods used in the basic research studies were subject to assessment and classification.

${ }^{3}$ Techniques: analysis of clients' non-formal opinions, analysis of evaluation reports, analysis of staff meeting reports, any reports, memos and regulations, analysis of presented speeches and published interviews, standardised open question survey, anonymous mail survey, the Piorkowski apparatus (diagnosis of psychomotor skills), self-monitoring checklists as to professional qualifications and behaviours, graphology (personality assessment), introspective analysis of behaviours in critical situations, manipulation and inspection of environmental elements, undisguised observation of real events of critical importance, disguised and participant observations, disguised observation of induced stressful situations, observation standardised on the basis of rating scales, probation period at a given post, samples of task-related behaviours, rating scales to measure lifestyles, condition simulating (controlling and manipulating variables that determine a researched phenomenon), thematic apperception test (diagnosis of achievement motivation), vocational skills test, intellectual aptitude tests, temper tests, tests related to given areas of knowledge, structured free-form interview, weighted application form, situational interview (evaluating behaviours in a given situation), structured interview (repeated questions, prepared beforehand), focused group interview.

${ }^{4}$ Only techniques used in the main research studies were subject to assessment and classification. 
- Experimental - the research studies involve searching for and verifying relations between two variables, with frequent variable manipulation.

- Diagnostic - the research studies whose goal is to determine (diagnose) the condition of the given subject, its properties and operational principles.

- Model-related - research studies whose goal is to reflect, in the best possible way, the researched subject by means of a selected model.

- Analytical-observation-based research studies whose goal is to detect operational structures and mechanisms of the researched subject.

The main process of the phase named 'Determining the character of the carried-out research' is to make a decision by the researcher as to verifying the defined research goal, through determining its character by means of assigning it to the indicated module elements phases.

Phase III-Determining the transparency of the research goal (Dźwigot, 2018) - the notion of transparency of the research goal undoubtedly plays an essential role as far as the selection of research methods and techniques is concerned. The research methods and techniques, as described in the source literature, identify both the way in which the research process is performed as well as the research goal. It is also confirmed by available classifications and divisions of research methods. In the present paper, the author adopted a widely-used division of goal transparency, i.e. division between nondisguised and disguised goals. Then, the author classified methodologically the starting point of the phase, achieved in the previous phase, as a set of research methods and techniques and an additional set of methods and techniques, classified as to the transparency of research goals.

- Research goal - non-disguised - the research subjects are aware of the goal of the research process in which they take part.

- Research goal-disguised - the research goal is known to the researcher alone.

Phase IV-Choosing a way in which the research study is conducted (Dźwigot, 2018) - Although a question of choosing a way of conducting research studies has been tackled in the source literature for many years, it nevertheless remains at issue. There are two popular divisions. The first division presents the researcher's commitment in the research process as participating and non-participating. The second division focuses directly on the way in which research studies are conducted, including direct and indirect ways.

- Indirect - the researcher is carrying out the research studies remotely, not participating personally in the study.

- Direct - the researcher is taking part in the study, participating actively in the whole research process.

- Participating - the researcher is taking part in the study, being 'inside' the researched subject.
- Non-participating - the researcher is 'outside' the researched subject; he/she does not interfere with the course of the research.

Phase V-Determining the size of the sample being researched (Dźwigot, 2018) - the said phase, due to a wide variety of methods and techniques available, indicates more precisely those samples that are the most essential for the correct course of the research process. As a result of the undertaken research actions, five divisions were defined, each phase describing constituents of the phase (i.e. below 20; from 20 to 50; from 50 to 100; from 100 to 250 ; above 250 ).

The effect of employing all constituents of the selection procedure covering methods and techniques is to achieve a suggested set of diagnosed and classified methods and techniques, as correlated to theses, hypotheses and/or research questions described each time by the author.

\section{Summary and research conclusions}

The aim of the paper was to present the tool for selecting research methods and techniques for a given research process, which tool was elaborated by the author of the paper (Dźwigot, 2018). The developed procedure consists of five phases that allow, in a considerable way, to answer any question which a researcher (both the academic and the practitioner) should pose to himself/ herself.

1. Identifying a research subject.

2. Determining the nature of the carried-out research.

3. Determining the transparency of the research goal.

4. Selecting a manner in which the study is to be conducted.

5. Determining the research sample size.

What is more, the application of the developed procedure eliminates the need to diagnose research methods and techniques, available in the literature, through the use of classification patterns corresponding to five components of the procedure phases.

Should it be impossible to make a classification, a researcher shall be obliged to assign, on his/her own, methods and techniques to the category defined by him or herself. For this purpose, he or she should make use of the previously described form containing separate components of the modules of the procedure for selecting methods and techniques for the research process in management sciences.

Furthermore, it needs to be underlined that the selection of research methods and techniques, with the use of the above-mentioned procedure, shall be followed by an analysis of posed theses, hypotheses or research questions, repeated from time to time. It means that the researcher should separately apply, for each posed hypothesis or research question, recommendations resulting from the developed procedure. It is explained by the diversity of research problems in the management sciences. 
The graphic representation of the described procedure has been created by means of the Business Process Model and Notation, (BPMN). It is graphic notation meant to illustrate business processes; it provides busi- nesses with opportunities to define and comprehend internal and external procedures by means of business process diagrams. Thus, it is possible to communicate on the basis of adopted standards (Woodfield, 2018).

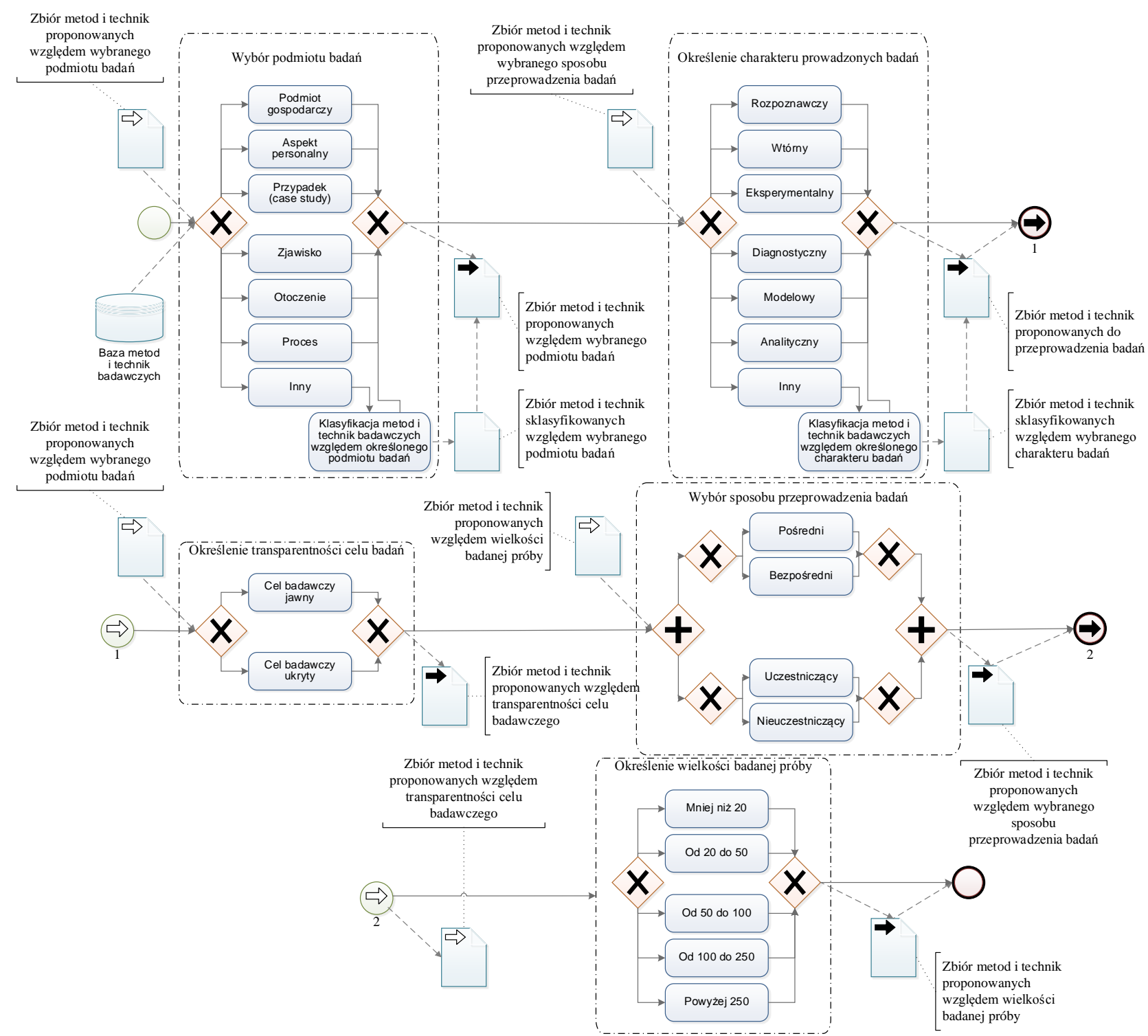

Figure. Procedure for selecting methods and techniques within the management-related research processes

Source: the author's own work.

Furthermore, due to research studies related to methods, procedures and approaches, it has been discovered which of these are the most essential for the research process and particular elements within management sciences. It allows one not only to determine the level of application of particular methods and techniques, or its amalgamation, but also to identify certain rules of recognising the research process within the given context, as well as other variables that might affect the importance of assigning correct methods and techniques to a given research process, with the view of enhancing the credibility, level and quality of the carried-out research studies.

\section{References}

1. Ansoff, H. I., Kipley, D., Lewis, A. O., Helm-Stevens, R., \& Ansoff, R. (2018). Implanting strategic management. Springer.

2. Ares, G. and Varela, P. (Eds.). (2018). Methods in Consumer Research, Volume 1: New Approaches to Classic Methods. UK, Woodhead Publishing, Elsevier, Duxford.

3. Barney, J. B., \& Hesterly, W. S. (2010). Strategic management and competitive advantage: Concepts and cases (pp. 4-25). Upper Saddle River, NJ: Prentice Hall.

4. Best, R., de Valence, G., \& Langston, C. (2007). Strategic management. In Workplace Strategies and Facilities Management (pp. 91-102). Routledge. 
5. Boiko, V., Kwilinski, A., Misiuk, M., \& Boiko, L. (2019). Competitive Advantages of Wholesale Markets of Agricultural Products as a Type of Entrepreneurial Activity: The Experience of Ukraine and Poland. Economic Annals-XXI, 175(1-2), pp. 68-72. https://doi.org/10.21003/ ea.V175-12.

6. Bryman, A. (2006) Integrating quantitative and qualitative research: How is it done? Qualitative Research, 6(1), pp. 3-37. https://doi.org/10.1177/146879410605 8877.

7. Czyżewski, B., Matuszczak, A., \& Miskiewicz, R. (2019). Public Goods Versus the Farm Price-Cost Squeeze: Shaping the Sustainability of the EU's Common Agricultural Policy. Technological and Economic Development of Economy, 25(1), pp. 82-102. https://doi.org/10.3846/ tede. 2019.7449

8. Cyfert, S., Glabiszewski, W., Krzakiewicz, K., \& Zastempowski, M. (2020). The Importance of Dynamic Capabilities in the Processes of Alignment of Chemical Industry Enterprises to Changes in the Environment. Przemysl Chemiczny, 99(6), pp. 953-956.

9. Czakon, W., Kawa, A., \& Scott, S. (2020). Network Orientation of Logistics Service Providers: The Construct, Dimensionality and Measurement Scale. International Journal of Logistics Research and Applications, 23(5), pp. 474-492. https://doi.org/10.1080/ 13675567.2019.1705260.

10. Chygryn, O., Bilan, Y., \& Kwilinski, A. (2020). Stakeholders of Green Competitiveness: Innovative Approaches for Creating Communicative System. Marketing and Management of Innovations, 3, pp. 356-368. https://doi.org/10.21272/mmi.2020.3-26.

11. Dalevska, N., Khobta, V., Kwilinski, A., \& Kravchenko, S. (2019). A Model for Estimating Social and Economic Indicators of Sustainable Development. Entrepreneurship and Sustainability Issues, 6(4), pp. 18391860. https://doi.org/10.9770/jesi.2019.6.4(21).

12. Danermark, B., Ekstrom, M., \& Jakobsen, L. (2005). Explaining society: An introduction to critical realism in the social sciences. Routledge.

13. Dementyev, V.V., \& Kwilinski, A. (2020). Institutsionalnaya sostavlyayuschaya izderzhek proizvodstva [Institutional Component of Production Costs]. Journal of Institutional Studies, 12(1), pp. 100-116. https: //doi.org/10.17835/2076-6297.2020.12.1.100-116 [in Russian].

14. Drozdz, W., Miskiewicz, R., Pokrzywniak, J., \& Elzanowski, F. (2019). Urban Electromobility in the Context of Industry 4.0. Torun, Wydawnictwo Adam Marszalek.

15. Drozdz, W., Marszalek-Kawa, J., Miskiewicz, R., \& Szczepanska-Waszczyna, K. (2020). Digital Economy in the Comporary World. Torun, Wydawnictwo Adam Marszalek.

16. Dubina, O., Us, Y., Pimonenko, T., \& Lyulyov, O. (2020). Customer Loyalty to Bank Services: The Bibliometric Analysis. Virtual Economics, 3(3), pp. 53-66. https://doi.org/10.34021/ve.2020.03.03(3).

17. Dyduch, W. (2019a). Entrepreneurial Strategy Stimulating Value Creation: Conceptual Findings and
Some Empirical Tests. Entrepreneurial Business and Economics Review, 7(3), pp. 65-82. https://doi.org/10.15678/ EBER.2019.070304.

18. Dyduch, W. (2019b). Organizational Design Supporting Innovativeness. Przeglad Organizacji, 6, pp. 1623. https://doi.org/10.33141/po.2019.06.02.

19. Dźwigoł, H. (2018). Współczesne procesy badawcze w naukach o zarządzaniu. Uwarunkowania metodyczne i metodologiczne. Warszawa, PWN.

20. Dzwigol, H. (2019a). The Concept of the System Approach of the Enterprise Restructuring Process. Virtual Economics, 2(4), pp. 46-70. https://doi.org/10.34021/ ve.2019.02.04(3).

21. Dzwigol, H. (2019b). Research Methods and Techniques in New Management Trends: Research Results. Virtual Economics, 2(1), pp. 31-48. https: //doi.org/10.34021/ve.2019.02.01(2).

22. Dzwigol, H. (2020a). Innovation in Marketing Research: Quantitative and Qualitative Analysis. Marketing and Management of Innovations, 1, pp. 128-135. http://doi.org/10.21272/mmi.2020.1-10.

23. Dzwigol, H. (2020b). Methodological and Empirical Platform of Triangulation in Strategic Management. Academy of Strategic Management Journal, 19(4), pp. 1-8.

24. Dźwigoł, H. (2020c). Interim Management as a New Approach to the Company Management. Review of Business and Economics Studies, 8(1), pp. 20-26. https://doi.org/10.26794/2308-944X-2020-8-1-20-26.

25. Dzwigol, H., \& Wolniak, R. (2018). Controlling w procesie zarządzania chemicznym przedsiębiorstwem produkcyjnym [Controlling in the management process of a chemical industry production company]. Przemysl Chemiczny, 97(7), pp. 1114-1116. https://doi.org/ 10.15199/62.2018.7.15.

26. Dzwigol, H., \& Dźwigoł-Barosz, M. (2018). Scientific Research Methodology in Management Sciences. Financial and Credit Activity: Problems of Theory and Practice, 2(25), pp. 424-437. https://doi.org/10.18371/ fcaptp.v2i25.136508.

27. Dzwigol, H., \& Dzwigol-Barosz, M. (2020). Sustainable Development of the Company on the Basis of Expert Assessment of the Investment Strategy. Academy of Strategic Management Journal, 19(5), pp. 1-7.

28. Dzwigol, H., Shcherbak, S., Semikina, M., Vinichenko, O., \& Vasiuta, V. (2019a). Formation of Strategic Change Management System at an Enterprise. Academy of Strategic Management Journal, 18(SI1), pp. 1-8.

29. Dzwigol, H., Aleinikova, O., Umanska, Y., Shmygol, N., \& Pushak, Y. (2019b). An Entrepreneurship Model for Assessing the Investment Attractiveness of Regions. Journal of Entrepreneurship Education, 22(1S), pp. 1-7.

30. Dzwigoł, H., Dzwigoł-Barosz, M., Zhyvko, Z., Miskiewicz, R., \& Pushak, H. (2019c). Evaluation of the Energy Security as a Component of National Security of the Country. Journal of Security and Sustainability Issues, 8(3), pp. 307-317. http://doi.org/10.9770/jssi.2019.8.3(2).

31. Dzwigol, H., Dźwigoł-Barosz, M., \& Kwilinski, A. (2020d). Formation of Global Competitive Enterprise Environment Based on Industry 4.0 Concept. International Journal of Entrepreneurship, 24(1), pp. 1-5. 
32. Dzwigol, H., Dzwigol-Barosz, M., Miskiewicz, R., \& Kwilinski, A. (2020). Manager Competency Assessment Model in the Conditions of Industry 4.0. Entrepreneurship and Sustainability Issues, 7(4), pp. 2630-2644. https://doi.org/10.9770/jesi.2020.7.4(5).

33. Furmaniak, S., Gauden, P.A., Patrykiejew, A., Miśkiewicz, R., \& Kowalczyk, P. (2018). Carbon Nanohorns as Reaction Nanochambers - a Systematic Monte Carlo Study. Scientific Reports, 15407. https://doi.org/10.1038/s41598-018-33725-z.

34. Furmaniak, S., Gauden, P.A., Patrykiejew, A., Miskiewicz, R., \& Kowalczyk, P. (2019a). The Effects of Confinement in Pores Built of Folded Graphene Sheets on the Equilibrium of Nitrogen Monoxide Dimerisation Reaction. Journal of Physics Condensed Matter, 31(13), 135001, pp. 1-12. https://doi.org/10.1088/1361-648X/ aaffb3.

35. Furmaniak, S., Gauden, P.A., Patrykiejew, A., Szymański, G., Miśkiewicz, R., \& Kowalczyk, P. (2019b). In Silico Study on the Effects of Carbonyl Groups on Chemical Equilibrium of Reactions with a Polar Product Occurring under Confinement in Pores of Activated Carbons. Chemical Engineering Communications, pp. 1-12. https://doi.org/10.1080/00986445.2019.1700115.

36. Gordon, R., Dibb S., Magee, Ch., Cooper, P., Waitt, G. (2018) Empirically testing the concept of valuein-behavior and its relevance for social marketing. Journal of Business Research, 82, pp.56-67. https: //doi.org/10.1016/j.jbusres.2017.08.035.

37. Gorynia, M., Trąpczyński, P., \& Bytniewski, S. (2019). The Concepts of Strategy and Business Models in Firm Internationalization Research: Towards a Research Agenda. International Entrepreneurship Review, 5(2), pp. 7-21. https://doi.org/10.15678/ier.2019.0502.01

38. Gorynia, M. (2019). Competition and Globalisation in Economic Sciences. Selected Aspects. Economics and Business Review, 5(3), pp. 118-133. https: //doi.org/10.18559/ebr.2019.3.7.

39. Hitt, M., \& Duane Ireland, R. (2017). The intersection of entrepreneurship and strategic management research. The Blackwell handbook of entrepreneurship, pp. 45-63.

40. Kamińska, B. (2018). Iterative signal processing in anticipatory management of industrial enterprise development. Virtual Economics, 1(1), pp. 53-65. https://doi.org/10.34021/ve.2018.01.01(4).

41. Kharazishvili, Y., Grishnova, O., \& Kamińska, B. (2019). Standards of living in Ukraine, Georgia, and Poland: identification and strategic planning. Virtual Economics, 2(2), pp. 7-36. https://doi.org/10.34021/ ve.2019.02.02(1).

42. Kharazishvili, Y., Kwilinski, A., Grishnova, O., \& Dzwigol, H. (2020). Social Safety of Society for Developing Countries to Meet Sustainable Development Standards: Indicators, Level, Strategic Benchmarks (with Calculations Based on the Case Study of Ukraine). Sustainability, 12(21), 8953. https://doi.org/10.3390/su12218953.

43. Klimas, P., Czakon, W., Kraus, S., Kailer, N., \& Maalaoui, A. (2020). Entrepreneurial Failure: A Synthesis and Conceptual Framework of its Effects. European Management Review. https://doi.org/10.1111/emre.12426.
44. Kondratenko, V., Okopnyk, O., Ziganto, L., \& Kwilinski, A. (2020). Innovation Development of Public Administration: Management and Legislation Features. Marketing and Management of Innovations, 1, pp. 87-94. https://doi.org/10.21272/mmi.2020.1-06.

45. Krzyżanowski, L. J. (1999). O podstawach kierowania organizacjami inaczej: paradygmaty, metafory, modele, filozofia, metodologia, dylematy i trendy. Warszawa, PWN.

46. Kuzior, A., Kwilinski, A., \& Tkachenko, V. (2019). Sustainable Development of Organizations Based on the Combinatorial Model of Artificial Intelligence. Entrepreneurship and Sustainability, 7(2), pp. 1353-1376. http://doi.org/10.9770/jesi.2019.7.2(39).

47. Kwilinski, A. (2017). Development of Industrial Enterprise in the Conditions of Formation of Information Economics. Thai Science Review, Autumn 2017, pp. 8590. https://doi.org/10.5281/zenodo.1414236.

48. Kwilinski, A. (2018a). Mechanism of Formation of Industrial Enterprise Development Strategy in the Information Economy. Virtual Economics, 1(1), pp. 7-25. https://doi.org/10.34021/ve.2018.01.01(1).

49. Kwilinski, A. (2018b). Mechanism of Modernization of Industrial Sphere of Industrial Enterprise in Accordance with Requirements of the Information Economy. Marketing and Management of Innovations, 4, pp. 116128. http://doi.org/10.21272/mmi.2018.4-11.

50. Kwilinski, A. (2018c). Mechanism for Assessing the Competitiveness of an Industrial Enterprise in the Information Economy. Research Papers in Economics and Finance, 3(1), pp. 7-16. https://doi.org/10.18559/ ref.2018.1.1

51. Kwilinski, A. (2018d). Trends of Development of the Information Economy of Ukraine in the Context of Ensuring the Communicative Component of Industrial Enterprises. Economics and Management, 1(77), pp. 64-70.

52. Kwilinski, A. (2019). Implementation of Blockchain Technology in Accounting Sphere. Academy of Accounting and Financial Studies Journal, 23(SI2), pp. 1-6.

53. Kwilinski, A., Tkachenko, V., \& Kuzior, A. (2019a). Transparent Cognitive Technologies to Ensure Sustainable Society Development. Journal of Security and Sustainability Issues, 9(2), pp. 561-570 http://doi.org/10.9770/jssi.2019.9.2(15).

54. Kwilinski, A., Drobyazko, S., \& Derevyanko, B. (2019b). Synergetic and Value Effects in Corporate Mergers and Acquisitions of International Companies. In Khalid S. Soliman (Ed.), Proceedings of the 34th International Business Information Management Association Conference (IBIMA) 13-14 November 2019. Vision 2025: Education Excellence and Management of Innovations through Sustainable Economic Competitive Advantage in 2019 (pp. 9467-9471). Madrid (Spain), IBIMA Publishing.

55. Kwilinski, A., Dalevska, N., Kravchenko, S., Hroznyi, I., Kovalenko, I. (2019c). Formation of the Entrepreneurship Model of E-Business in the Context of the Introduction of Information and Communication Technologies. Journal of Entrepreneurship Education, Vol. 22, Issue 1S, 1528-2651-22-S1-337: 1-7.

56. Kwilinski, A., Ruzhytskyi, I., Patlachuk, V., Patlachuk, O., \& Kaminska, B. (2019d). Environmental Taxes as a Condition of Business Responsibility in the 
Conditions of Sustainable Development. Journal of Legal, Ethical and Regulatory Issues, 22(SI2) 1544-0044-22-SI2-354: 1-6.

57. Kwilinski, A., Volynets, R., Berdnik, I., Holovko, M., \& Berzin, P. (2019e). E-Commerce: Concept and Legal Regulation in Modern Economic Conditions. Journal of Legal, Ethical and Regulatory Issues, 22(SI2), 15440044-22-SI-2-357: 1-6.

58. Kwilinski, A., Dzwigol, H., \& Dementyev, V. (2019f). Transnational Corporations as Entities of International Entrepreneurship. International Journal of Entrepreneurship, 23(SI4), 1-6.

59. Kwilinski, A., Pajak, K., Halachenko, O., Vasylchak, S., Pushak, Ya., \& Kuzior, P. (2019g). Marketing Tools for Improving Enterprise Performance in the Context of Social and Economic Security of the State: Innovative Approaches to Assessment. Marketing and Management of Innovations, 4, pp. 172-181. http://doi.org/10.21272/ mmi.2019.4-14

60. Kwilinski, A., \& Kuzior, A. (2020). Cognitive Technologies in the Management and Formation of Directions of the Priority Development of Industrial Enterprises. Management Systems in Production Engineering, 28(2), pp. 119-123. http://doi.org/10.1515/mspe-2019-0020.

61. Kwilinski, A., Vyshnevskyi, O. \& Dzwigol, H. (2020a). Digitalization of the EU Economies and People at Risk of Poverty or Social Exclusion. Journal of Risk and Financial Management, 13(7), pp. 142. https: //doi.org/10.3390/jrfm13070142.

62. Kwilinski, A., Zaloznova, Y., Trushkina, N. \& Rynkevych, N. (2020b). Organizational and Methodological Support for Ukrainian Coal Enterprises Marketing Activity Improvement. E3S Web of Conferences, 168, 00031. https://doi.org/10.1051/e3sconf/202016800031.

63. Kwilinski, A., Dielini, M., Mazuryk, O., Filippov, V., \& Kitseliuk, V. (2020c). System Constructs for the Investment Security of a Country. Journal of Security and Sustainability Issues, 10(1), pp. 345-358. https: //doi.org/10.9770/jssi.2020.10.1(25).

64. Labarca C. (2017), Qualitative Research for beginners. Maracaibo, Venezuela.

65. Lakhno, V., Malyukov, V., Bochulia, T., Hipters, Z., Kwilinski, A., \& Tomashevska, O. (2018). Model of Managing of the Procedure of Mutual Financial Investing in Information Technologies and Smart City Systems. International Journal of Civil Engineering and Technology, 9(8), pp. 1802-1812.

66. Lyashenko, V., \& Pidorycheva, I. (2019). The formation of interstate and cross-border scientific-educational and innovative spaces between Ukraine and the European Union member states in the digital economy. Virtual Economics, 2(2), pp. 48-60. https://doi.org/10.34021/ ve.2019.02.02(3).

67. Miskiewicz, R. (2017a). Knowledge in the Process of Enterprise Acquisition. Progress in Economic Sciences, 4, pp. 415-432. https://doi.org/10.14595/PES/04/ 029.

68. Miskiewicz, R. (2017b). Knowledge Transfer in Merger and Acquisition Processes in the Metallurgical Industry. Warsaw, PWN.

69. Miskiewicz, R. (2018). The Importance of Knowledge Transfer on the Energy Market. Polityka Ener- getyczna, 21(2), pp. 49-62. http://dx.doi.org/10.24425 $\% 2 \mathrm{~F} 122774$

70. Miśkiewicz, J. (2019a). The merger of natural intelligence with artificial intelligence, with a focus on Neuralink company. Virtual Economics, 2(3), pp. 22-29. https://doi.org/10.34021/ve.2019.02.03(2).

71. Miskiewicz, R. (2019b). Challenges Facing Management Practice in the Light of Industry 4.0: The Example of Poland. Virtual Economics, 2(2), pp. 37-47. https://doi.org/10.34021/ve.2019.02.02(2)

72. Miskiewicz, R. (2020). Internet of Things in Marketing: Bibliometric Analysis. Marketing and Management of Innovations, 3, pp. 371-381. http: //doi.org/10.21272/mmi.2020.3-27.

73. Miśkiewicz, R, \& Wolniak, R. (2020). Practical Application of the Industry 4.0 Concept in a Steel Company. Sustainability, 12(14), 5776. https://doi.org/10.3390/ su12145776.

74. Ogiela, L. D. (2017). Cognitive information systems in management sciences. Morgan Kaufmann.

75. Pająk, K., Kamińska, B., \& Kvilinskyi, O. (2016). Modern Trends of Financial Sector Development under the Virtual Regionalization Conditions. Financial and Credit Activity: Problems of Theory and Practice, 2(21), pp. 204217. https://doi.org/10.18371/fcaptp.v2i21.91052.

76. Pająk, K., Kvilinskyi, O., Fasiecka, O., \& Miskiewicz, R. (2017). Energy security in regional policy in Wielkopolska region of Poland. Economics and Environment, 2(61), pp. 122-138.

77. Punch, K. F. (2016). Developing Effective Research Proposals. 3rd Edition. SAGE Publications Ltd.

78. Quian, D. (2018). Adaptive Control: Methods, Applications and Research. Nova Science Publishers, Inc.

79. Quinton, S., Reynolds, N. (2018). Understanding Research in the Digital Age. London, SAGE Publications Ltd.

80. Raziq, A. \& Wiesner, R. (2016). High performance management practices and sustainability of SMEs. Evidence from manufacturing and services-based industries in Pakistan. Journal of Management Sciences, 3(2), pp. 83-107.

81. Robbins, D. (2009). Understanding research methods. A guide for the public and nonprofit manager., USA, CRC Press, Taylor \& Francis Group, Boca Raton.

82. Saługa, P. W., Szczepańska-Woszczyna, K., Miśkiewicz, R. \& Chłąd, M. (2020). Cost of Equity of CoalFired Power Generation Projects in Poland: Its Importance for the Management of Decision-Making Process. Energies, 13(18), 4833. https://doi.org/10.3390/en13184833.

83. Savchenko, T., Basiurkina, N., Rodina, O. \& Kwilinski, A. (2019). Improvement of the Assessment Methods of Product Competitiveness of the Specialized Poultry Enterprises. Management Theory and Studies for Rural Business and Infrastructure Development, 41(1), pp. 43-61. https://doi.org/10.15544/mts.2019.05.

84. Thomas G., 2017, How to Do Your Research Project: A Guide for Students. London, Sage.

85. Tkachenko, V., Kwilinski, A., Korystin, O., Svyrydiuk, N. \& Tkachenko, I. (2019a). Assessment of Information Technologies Influence on Financial Security of Economy. Journal of Security and Sustainability, 8(3), pp. 375-385. http://doi.org/10.9770/jssi.2019.8.3(7). 
86. Tkachenko, V., Kwilinski, A., Klymchuk, M. \& Tkachenko, I. (2019b). The Economic-Mathematical Development of Buildings Construction Model Optimization on the Basis of Digital Economy. Management Systems in Production Engineering, 27(2), pp. 119-123. http: //doi.org/10.1515/mspe-2019-0020.

87. Tkachenko, V., Kwilinski, A., Tkachenko, I. \& Puzyrova, P. (2019c). Theoretical and Methodical Approaches to the Definition of Marketing Risks Management Concept at Industrial Enterprises. Marketing and Management of Innovations, 2, pp. 228-238. http://doi.org/10.21272/mmi.2019.2-20

88. Tkachenko, V., Kwilinski, A., Kaminska, B., Tkachenko, I. \& Puzyrova, P. (2019d). Development and Effectiveness of Financial Potential Management of Enterprises in Modern Conditions. Financial and Credit Activity: Problems of Theory and Practice, 3(30), pp. 85-94. https://doi.org/10.18371/fcaptp.v3i30.179513.

89. Tkachenko, V., Kuzior, A., \& Kwilinski, A. (2019e). Introduction of Artificial Intelligence Tools into the Training Methods of Entrepreneurship Activities. Journal of Entrepreneurship Education, 22(6), pp. 1-10.

90. Trapczyński, P., Gorynia, M., Nowak, J. \& Wolniak, R. (2019). EU Countries from Central and Eastern Europe, and the Investment Development Path Model: A New Assessment. Argumenta Oeconomica, 2(43), pp. 385-406. https://doi.org/10.15611/aoe.2019.2.16.

91. Trigeorgis, L., \& Reuer, J. J. (2017). Real options theory in strategic management. Strategic Management Journal, 38(1), pp. 42-63.

92. Trushkina, N., Abazov, R., Rynkevych, N. \& Bakhautdinova, G. (2020). Digital Transformation of Organizational Culture under Conditions of the Information Economy. Virtual Economics, 3(1), pp. 7-38. https://doi.org/10.34021/ve.2020.03.01(1).

93. Vaivio, J., \& Sirén, A. (2010). Insights into method triangulation and "paradigms" in interpretive management accounting research. Management Accounting Research, 21(2), pp. 130-141, https://doi.org/10.1016/ j.mar.2010.03.001.

94. Vyshnevskyi, O. (2019). Unity of digital and virtual economies within concept of Dataism. Virtual Economics, 2(3), pp. 7-21. https://doi.org/10.34021/ ve.2019.02.03(1).

95. Woodfield, K. (Ed.). (2018). The Ethics of Online Research (Advances in Research Ethics and Integrity)., Bingley (UK), Emerald Publishing Limited.

96. Yelnikova, Y., \& Miskiewicz, R. (2020). Implementation Mechanism of Impact Investing in the Post-Conflict Regions. Financial Markets. Institutions and Risks, 4(3), pp. 53-65. https://doi.org/10.21272/fmir.4(3).5362.2020 .

97. Zaloznova, Y., \& Trushkina, N. (2019). Management of logistic activities as a mechanism for providing sustainable development of enterprises in the digital economy. Virtual Economics, 2(1), pp. 64-81. https: //doi.org/10.34021/ve.2019.02.01(4)
98. Zastempowski, M., Glabiszewski, W., Krukowski, K., \& Cyfert, S. (2020). Technological Innovation Capabilities of Small and Medium-Sized Enterprises. European Research Studies, 23(3), pp. 460-474.

Джвігол X. Інструментарій адаптації методів і технік у дослідних процесах

У статті представлено розроблені автором інструменти для адаптації методів та технік у дослідницьких процесах. Для оцінки та відбору окремих методів та прийомів дослідження в роботі було залучено групову оцінку експертів. Розроблений інструментарій складається 3 п'яти фаз, що дозволяють відповісти на будьяке питання, яке дослідник (вчений та практик) повинен поставити перед собою. Більше того, застосування інструментарію позбавляє потреби діагностувати доступні в літературі методи та прийоми дослідження, використовуючи шаблон класифікації, який відповідає п’яти компонентам етапів процедури.

Ключові слова: дослідницький процес, методи, техніки, прийоми, інструментарій, науки про управління.

Dzwigol H. Tools for Adjusting Research Methods and Techniques to Research Processes

The aim of the following paper is to present the tools for adjusting research methods and techniques to research processes, developed by the author hereof. In order to evaluate and select individual research methods and techniques, a group evaluation of experts was employed in the paper. The developed tool consists of five phases that allow to answer any question which a researcher (academic and practitioner) should pose to himself/herself. What is more, the application of the tool eliminates a need to diagnose research methods and techniques available in the literature, through the use of a classification pattern which corresponds to five components of the procedure phases.

Keywords: research process, methods, techniques, tools, management sciences.

Джвигол Х. Инструментарий адаптации методов и техник в исследовательских процессах

В статье представлены разработанные автором инструменты для адаптации методов и техник в исследовательских процессах. Для оценки и отбора отдельных методов и приемов исследования в работе была использована групповая оценка экспертов. Разработанный инструментарий состоит из пяти фаз, позволяющих ответить на любой вопрос, который исследователь (ученый и практик) должен поставить перед собой. Более того, применение инструментария исключает необходимость диагностировать доступные в литературе методы и приемы исследования, используя шаблон классификации, который соответствует пяти компонентам этапов процедуры.

Ключевые слова: исследовательский процесс, методы, техники, приемы, инструментарий, науки об управлении.

Received by the editors: 20.11.2020

and final form 29.12.2020 